Tasting Qualities 
ATELIER: ETHNOGRAPHIC INQUIRY IN THE TWENTY-FIRST CENTURY

Kevin Lewis O'Neill, Series Editor

I. Mortal Doubt: Transnational Gangs and Social Order in Guatemala City, by Anthony W. Fontes

2. Contingent Kinship: The Flows and Futures of Adoption in the United States, by Kathryn A. Mariner

3. Captured at Sea: Piracy and Protection in the Indian Ocean, by Jatin Dua

4. Fires of Gold: Law, Spirit, and Sacrificial Labor in Ghana, by Lauren Coyle Rosen

5. Tasting Qualities: The Past and Future of Tea, by Sarah Besky 


\section{Tasting Qualities}

THE PAST AND FUTURE OF TEA

Sarah Besky

\section{口}

U NIVERSITY OF CALIFORNIA PRESS 
University of California Press

Oakland, California

(C) 2020 by Sarah Besky

Library of Congress Cataloging-in-Publication Data

Names: Besky, Sarah, author.

Title: Tasting qualities : the past and future of tea / Sarah Besky.

Other titles: Atelier (Oakland, Calif.) ; 5.

Description: Oakland, California : University of California Press, [2020] | Series: Atelier: ethnographic inquiry in the twenty-first century; 5 | Includes bibliographical references and index.

Identifiers: LCCN 2019042808 (print) | LCCN 2019042809 (ebook) | ISBN 9780520303249 (cloth) | ISBN 9780520303256 (paperback) | ISBN 9780520972704 (ebook)

Subjects: LCsH: Tea trade-India-Quality control.

Classification: LCC HD9198.I42 B 472020 (print) | LCC HD9198.I42 (ebook) | DDC $338.1 / 73720954-\mathrm{dc} 23$

LC record available at https://lccn.loc.gov/2019042808

LC ebook record available at https://lccn.loc.gov/2019042809

Manufactured in the United States of America

$\begin{array}{llllllll}25 & 24 & 23 & 22 & 21 & 20 & 19 & 20\end{array}$

$\begin{array}{llllllllll}\text { IO } & 9 & 8 & 7 & 6 & 5 & 4 & 3 & 2 & \text { I }\end{array}$ 